\title{
Prefácio
}

\section{DA AUTONOMIA NA APRENDIZAGEM \\ À AUTONOMIA NO ENSINO DE LÍNGUAS}

Este volume teve origem na visita de Phil Benson ao Brasil em 2007 e nas discussões que ele conduziu com dois grupos de pesquisadores brasileiros, um na UFMG e outro na PUC-SP.

O volume começa com o relato crítico de Benson e Huang sobre como o interesse nos estudos sobre autonomia na aprendizagem se desenvolveu e se transformou, ligando-se agora à autonomia no ensino de línguas. Os autores resenham o desenvolvimento conceitual da autonomia de professores ao longo de três fases principais: uma que focaliza os papéis de professores em projetos de aprendizagem com autonomia, outra relativa ao desenvolvimento profissional e uma terceira centrada na liberdade profissional. Os autores também propõem uma concepção alternativa baseada na noção de transição de autonomia na aprendizagem para a autonomia no ensino.

No segundo artigo, Paiva e Braga se apóiam na Teoria da Complexidade para desenvolver uma discussão sobre a natureza complexa da autonomia, oferecendo evidências muito interessantes, provenientes de um corpus de 80 narrativas de aprendizagem de inglês como língua estrangeira.

Nos dois trabalhos seguintes, as pesquisadoras examinam diferentes aspectos relacionados à autonomia do aprendiz e do professor, no contexto de cursos de graduação em línguas modernas, em que a maioria dos alunos está interessada em tornar-se professor de inglês.

No primeiro, Magno e Silva apresentam uma proposta para o desenvolvimento de autonomia, partindo do pressuposto que as atividades extraclasse, de livre iniciativa dos alunos, constituem-se em um relevante aspecto da aprendizagem de línguas. Essa proposta reúne aspectos relativos às dificuldades inerentes ao processo de aprendizagem de línguas, aos estilos de aprendizagem, ao uso de ferramentas tecnológicas para melhorar os níveis de 
autonomia, ao desenvolvimento de estratégias de aprendizagem de línguas e à implementação de rotinas de auto-monitoramento e auto-avaliação.

No segundo, com base na pedagogia crítica de Paulo Freire, Nicolaides e Fernandes argumentam que o ambiente social em que acontece a aprendizagem e as oportunidades que o ambiente pode gerar desempenham um papel importante no desenvolvimento da autonomia. Para ilustrar o argumento, as autoras apresentam um estudo de caso de um aprendiz de línguas em nível de graduação, um aluno rebelde na opinião de alguns de seus professores, e descrevem algumas das transformações pelas quais ele passa durante seu processo de aprendizagem.

Os quatro trabalhos que fecham o volume tocam em diferentes aspectos da aprendizagem e da autonomia do professor em contextos de programas de desenvolvimento em serviço.

Mello, Dutra e Jorge estão preocupadas com o papel da pesquisa-ação colaborativa no desenvolvimento da autonomia do professor. Em seu trabalho, apresentam as características de um programa de um ano desenvolvido com professores, os insights que tiveram durante o processo e os resultados desse trabalho.

Em um contexto online de desenvolvimento de professores a distancia, Collins analisa mensagens de fóruns de discussão assíncrona e identifica possíveis evidências de desenvolvimento de autonomia. Baseando-se em literatura das áreas da aprendizagem a distância (Garrison et al. 2003), do desenvolvimento de autonomia (Benson 2001) e da Lingüística SistêmicoFuncional (Halliday \& Matthiessen 2004; Martin \& Rose 2003) e em seus resultados, ela discute possíveis conexões entre a aprendizagem a distância online, o desenvolvimento da autonomia e o uso de linguagem.

Ainda no contexto de programas de formação continuada online, Sprenger e Wadt descrevem o processo de atualização de um programa de curso originalmente voltado para o desenvolvimento de autonomia do professor. Para esse processo de atualização, elas levam em conta as reações e avaliações dos participantes em relação à primeira versão do curso, o novo contexto em que o curso será realizado e os desenvolvimentos teóricos relacionados à autonomia do aprendiz e do professor, incluindo-se aí pesquisas 
que utilizam narrativas de aprendizes e professores e suas conexões com o desenvolvimento da autonomia do professor.

O último trabalho do volume apresenta um recorte da pesquisa de Sprenger (2004) e mostra uma forma de observar o processo de desenvolvimento da autonomia de professores. Lançando mão do instrumental teórico originado na teoria da atividade (Leontiev 1978; Engeström 1987, 1999), a autora enfoca as contradições referentes aos tópicos de conversação mais freqüentes e o processo de resolução das mesmas. Seus dados incluem mensagens publicadas no fórum de discussão, o registro de interações em sessões de chat, comunicação via email, além do diário reflexivo e materiais didáticos produzidos pelas professoras.

Esta coleção de trabalhos, provenientes de sete diferentes universidades, oferece ao leitor uma gama ampla e interessante de preocupações relativas à aprendizagem, ao ensino e ao desenvolvimento da autonomia. A oportunidade que tivemos de discutir esses trabalhos e agora apresentá-los é para nós importante e valiosa. Esperamos que o leitor a perceba como uma boa contribuição para suas próprias reflexões sobre o desenvolvimento da autonomia no ensino e na aprendizagem.

Phil Benson

Heloisa Collins

Terezinha Maria Sprenger

Setembro 2008 